\title{
The impact of regional autonomy and monetary crisis on economic growth in Yogyakarta
}

\author{
Sarastri Mumpuni Ruchba ${ }^{1}$, Ferdy Suhada ${ }^{2}$ \\ ${ }^{1,2}$ Department of Economics, Universitas Islam Indonesia, Yogyakarta, Indonesia \\ e-mail: mruchba@yahoo.com
}

\begin{tabular}{l} 
Article Info \\
Article history: \\
Received : 15 January 2015 \\
Accepted : 3 March 2015 \\
Published: 1 April 2015 \\
\hline \\
Keywords: \\
Economic growth, monetary \\
crisis, regional autonomy
\end{tabular}

\section{JEL Classification:}

$\mathrm{O} 12, \mathrm{O} 18, \mathrm{O} 43$

DOI:

http://dx.doi.org/10.20885/ ejem.vol7.iss1.art6

\begin{abstract}
This study analyzes the impact of some factors, especially the implementation of autonomy and monetary crisis on economic growth in Yogyakarta Special Province. The independent variables entered into the model are investment, labor force and government spending, as well as two dummy variables, namely the financial crisis and the 1990-2013 regional autonomy implementations. This study uses multiple linear regression analysis with Ordinary Least Square (OLS). This study finds that investment and regional autonomy do not affect the economic growth in Yogyakarta, while labor force and monetary crisis negatively affect economic growth. The study also finds that government spending has a positive influence on economic growth.
\end{abstract}

\begin{abstract}
Abstrak
Penelitian ini menganalisis faktor-faktor yang mempengaruhi pertumbuhan ekonomi di Daerah Istimewa Yogyakarta (DIY). Variabel-variabel bebas yang dimasukkan kedalam model adalah investasi, tenaga kerja dan pengeluaran pemerintah, serta dua variabel dummy berupa krisis moneter dan pemberlakuan otonomi daerah 1990-2013. Penelitian ini menggunakan analisis regresi linier berganda dengan Ordinary Least Square $(O L S)$. Penelitian ini menemukan bahwa investasi dan otonomi daerah tidak berpengaruh terhadap pertumbuhan ekonomi di DIY, sedangkan tenaga kerja dan krisis moneter berpengaruh negatif terhadap pertumbuhan ekonomi. Penelitian ini juga menemukan bahwa pengeluaran pemerintah berpengaruh positif terhadap pertumbuhan ekonomi.
\end{abstract}

\section{Introduction}

A regional economic development is a process in which a regional government and people manage resources and build a partnership between a regional government and a private sector to create jobs and stimulate the regional economic development. A regional economic development is a progress of economic activities that increases a production of goods and services and in turn improves people's prosperity. An economic growth is prompted by embarking a regional autonomy for the autonomy gives regional governments an extensive authority to govern, develop and explore their potentials.
Investment is spending to procure capital goods encompassing selfproduction, buying new local capital goods, new or second foreign capital goods after selling capital goods or giving them to others. Capital goods are goods or tools used in production and one year or more working capitals are called fixed capital goods while gross indicates that investment does not consider the depreciation of capital goods yet. Researches on investment were done by some economists in many countries (Baek dan Koo, 2009; Clowes, 2010; Cheong, and $\mathrm{Wu}, 2013$; Cheung, 2014).

Chamberlin (2010) in his article says that when the recession lasted in UK 
net exports contributed beneficially to the economic growth. At the end of the economic recession the contribution got more significant. Furthermore Chamberlin writes the phenomenon explained most of that domestic burden came from domestic consumption and investment which influenced beneficially on the economic growth.

Developing countries are considered as weak ones that are open and vary to respond to world economic liberalization. Trade liberalization particularly WTO is also concerned with environmental issues in producing goods (Brooks, 1998). Governments need to respond the environmental issue regarded to imported and exported goods. Governments have some options to respond it by taxing policy or others. Cole et al. (2011) did a research on the issue in China and proposed that the issue affects a country inviting foreign investors. The amount of foreign direct investment (FDI) also is closely related to Indonesia economic growth (Hakim, 2011).

Economic performance is characterized by increasing speed of economic growth and per capita income and better regionally dispersed development. Fan et al. (2011) state three strategies to disperse fairly economic growth to regions namely (a) infrastructure, (b) social investment and protection and (c) government reform. Additionally, economic growth depends on investment purchase of infrastructure (Prasetyo et al., 2013). The availability and quality of infrastructure financed by government or private investment are keys of economic progress affecting the Indonesian national economic growth (Ferdinan, 2013).

The Indonesia case is similar with the China one as Shindo (2010) studied that the government expenditure is connected to the fairly wide disparity of regional prosperity level. But the big difference between Indonesia and China is that the change of fiscal policy in terms of economic decentralization increased the Indonesia economic growth (Badrudin, 2011). The decentra- lization policy is basically shifting wider political and economic authority to regional governments and so regional governments tend to set and execute development policies more effectively. In turn the economic growth will be faster and regional public prosperity will get better. The national economic growth reflects the regional one (Razak, 2011).

The execution of regional autonomy policy in 1999 is a response to the monetary crisis since 1997 in Asian countries including Indonesia. Some well-known economists gave an initial diagnosis of the crisis. They calculated that when very large capital inflow went to Asian countries whose economic fundamentals are not so strong, it will be too risky to blow a monetary crisis. It was worse because bad governance and governmental economic policy (Radelet and Sachs, 1998). The economic growth of Asian countries dropped and in 1998 the Indonesian economic growth was $-13 \%$. Barro (2001) was not sure that the growth would be as the rate befor the crisis eventhough the economic recovery went fast. It was indicated by the small investment ratio and the low share index. However, Barro's study reports that the impact of the economic crisis on the growth will not be more than five years.

Since the regional aotonomy as the consequence of the reformation began in Indonesia the economics has been growing more dynamically. It needs to analyze determinants of the Indonesian economic growth along the regional autonomy. The research findings will be references for the government to make policies in order to realize better economic performance.

\section{Research Method}

The research makes use of secondary data systematically written in terms of time series data. The data are a development of the economic growth, investment, workforce and 1990-2013 government expenditure and monetary crisis and regional autonomy 
as two dummy variables. The research employs multiple linear regression analysis with Ordinary Least Square (OLS) to examine the effect of investment, workforce, government expenditure, dummy monetary crisis and regional autonomy on the economic growth in the Yogyakarta special province. The model is:

$Y=\beta_{0}+\beta_{1} X_{1}+\beta_{2} X_{2}+\beta_{3} X_{3}+\beta_{4} D_{1}+\beta_{5} D_{2}$

Notes:

$Y \quad=$ economic growth $(\%)$

$\beta_{0}=$ intercept

$\beta_{1}-\beta_{5}=$ regression coefficient

$X_{1}=$ investment (billion rupiahs)

$X_{2}=$ workforce (million persons)

$X_{3}=$ government expenditure (billion rupiahs)

$D_{1}=$ monetary crisis 1997

$D_{1}=1$, after crisis at $1998-2013$

$D_{1}=0$, before crisis at $1990-1997$

$D_{2} \quad=$ policy of regional autonomy

$D_{2}=1$, after the regional autonomy in 2001-2013

$D_{2}=0$, before the regional autonomy 1990-2000

\section{Result and Discussion}

\section{Yogyakarta Special Territory Economy}

The economic growth of the YST went dynamically and better than that of other provinces (Table 1). Based on Table 1, we see that the GDP of provinces in Java vary. This suggests that each area has a different potential Jakarta the Capital City has the highest GDP, while Yogyakarta Special Territory (YST) has the lowest one. Nevertheless, economic growth in YST increased over the last six years.

Figure 1 shows that the economic growth in the YST fluctuates. Economic growth was at the highest in 1994, namely $8.11 \%$. the lowest growth occurred in 1997 , namely $-11.18 \%$, as the impact of the economic crisis in Asia. Economic growth prior to the implementation of regional autonomy, namely $1990-2000$, was quite good, with an average of $4.02 \%$. Average economic growth enlarges in the period of regional autonomy implementation, 20012013 , which amounted to $4.72 \%$. The implementation of regional autonomy is expected to motivate YST to promote creativity and initiative in exploring and developing the potentials that exist in YST, so as to boost economic growth in the region.

Investments are purchases of corporate or investors on capital goods to increase the ability to produce goods and services. Investments are divided into the Domestic Investment (DCI) Foreign Direct Investment (FDI). Increased investment could boost economic growth.

YST,as a tourist destination and city of students, has the potential to grow. YST has abundant resources that attract many investors, both domestic and foreign ones. Realization of investments in YST throughout 2008-2013 can be seen in Table 2.

Table 1: 2008-2013 Regional Gross Domestic Product of Provinces in the Java Island (Billion Rupiahs)

\begin{tabular}{rcrrrc}
\hline Year & Jakarta & \multicolumn{1}{c}{ West Java } & Central Java & \multicolumn{1}{c}{ Yogyakarta } & East Java \\
\hline 2013 & 477285,25 & 386838,84 & 223099,74 & 24567,48 & 419428,45 \\
2012 & 449805,42 & 364752,40 & 201848,42 & 23308,56 & 393662,85 \\
2011 & 422242,25 & 343193,56 & 198270,12 & 22131,77 & 366983,28 \\
2010 & 395622,44 & 322223,82 & 186992,99 & 21044,26 & 342280,76 \\
2009 & 371469,50 & 303405,25 & 176673,46 & 20064,26 & 320861,17 \\
2008 & 353723,39 & 291250,84 & 168034,48 & 19212,48 & 305538,69 \\
\hline
\end{tabular}

Source: BPS, Statistik Indonesia 2014 


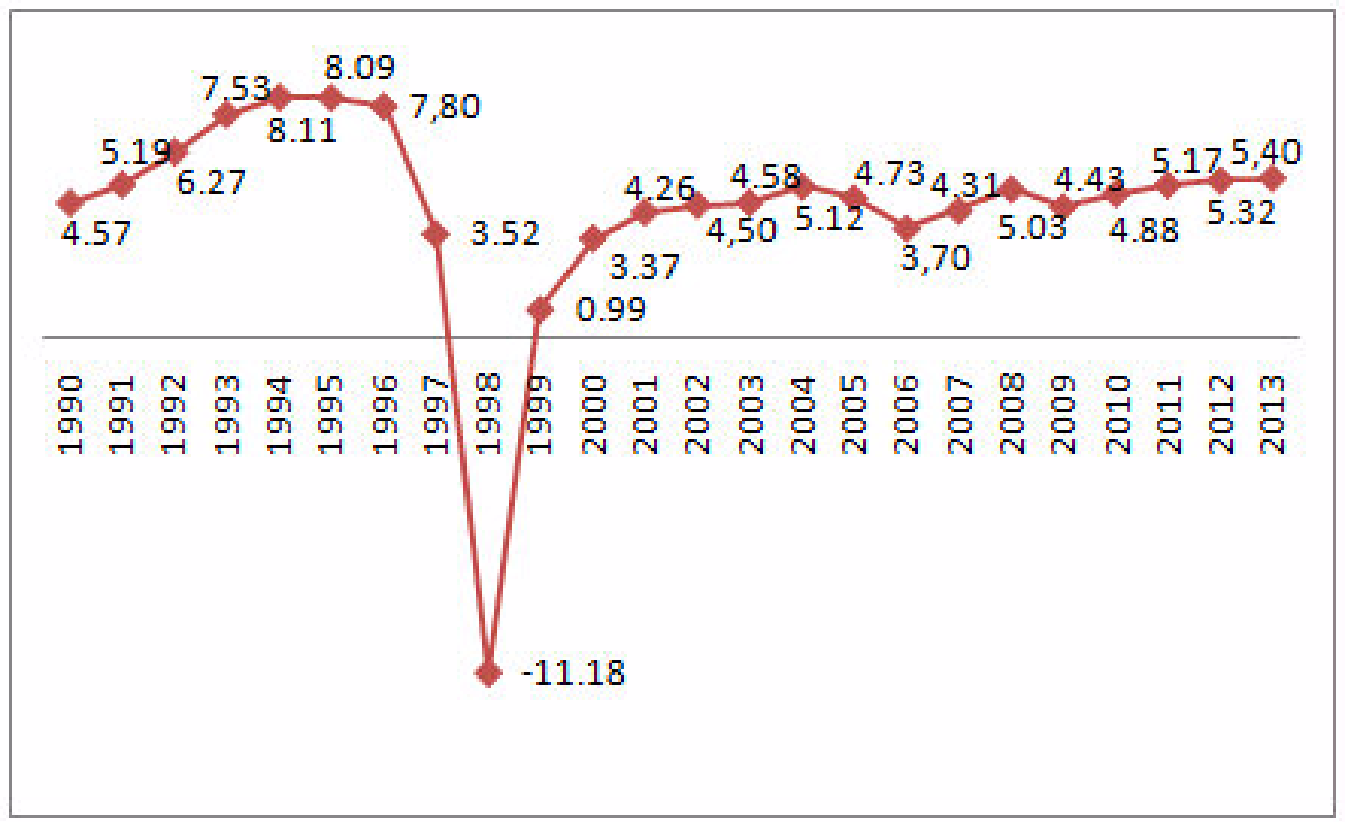

Source: BPS provinsi Yogyakarta

Figure 1: Economic Growth based on Constant Price in YST, 1990 - 2013 (Percent)

Table 2: Investments Realization in YST, 2008-2013 (Rp Billion)

\begin{tabular}{rrr}
\hline Year & \multicolumn{1}{c}{ DCI } & \multicolumn{1}{c}{ FDI } \\
\hline 2013 & 283,8 & 305,8 \\
2012 & 334 & 796,8 \\
2011 & 195,8 & 21,0 \\
2010 & 90,9 & 44,5 \\
2009 & 32,9 & 84,2 \\
\hline
\end{tabular}

Sumber: Badan Pusat Statistik Yogyakarta, 2014

In addition to investments, the labor force is also a factor that affects the output of a region. A large labor force will be formed from a large population. The local government has an obligation to create employment opportunities. New employment opportunities increase incomes and purchasing power. The creation of public income may also encourage investments from internal areas that will boost economic growth in the region.

GDRP growth as a measure of economic growth in the area is affected by government spending in the public service sector. Total government expenditure is measured from routine expenditure and development expenditure allocated in the local budget. The greater the productive gov- ernment spending, the greater the level of the economy of a region is. In general, government spending had a positive impact on economic growth.

The realization of government spending in YST during 2009-2013 tends to increase from year to year (Table 4).

Table 3: Labor Force in YST, 2009-2013 (People)

\begin{tabular}{lc}
\hline Year & Labor force \\
\hline 2013 & 1.949 .243 \\
2012 & 1.988 .539 \\
2011 & 1.933 .917 \\
2010 & 1.882 .296 \\
2009 & 2.016 .694 \\
\hline
\end{tabular}

Source: Badan Pusat Statistik Yogyakarta, 2014

Table 4: Realization of Government Spending in YST, 2009 - 2013 (Rp billion)

\begin{tabular}{cc}
\hline Year & Government Spending \\
\hline 2009 & 4.454 .790 .770 \\
2010 & 4.761 .718 .607 \\
2011 & 5.580 .650 .884 \\
2012 & 6.529 .560 .492 \\
2013 & 6.458 .852 .843 \\
\hline
\end{tabular}

Source: Badan Pusat Statistik Yogyakarta, 2014. 


\section{Regression analysis results}

This study includes three quantitative variables in the regression model, namely investment, labor and government spending, as well as two dummy variables, namely the financial crisis and regional autonomy. The dependent variable in this study is the economic growth of YST. Data ranges from 1990 to 2013. An analysis of the data processing shows the results as shown in Tables 5.

\section{Multicollinearity test}

To determine the existence of multicollinearity, this study calculates the partial correlation $(r)$ across the independent variables. The existence of multicollinearity is marked with indicators that exceed 0.85 .

Based on the results of these correlations, it can be concluded that there are several variables that have a correlation of higher than 0.85 , which means that there is a multicollinearity problem. The existence of multicollinearity does not affect the nature of BLUE. Thus, there is no independent variables were excluded from the modelthat has been designed.

\section{Heteroskedasticity test}

The existence of heteroskedasticity might lead to an inefficient estimator, so BLUE cannot be obtained. This study uses White Heteroskedasticity test to detect the presence of heteroskedasticity. If the value of chi-square probability is greater than the significance level $(\alpha=10 \%)$, then we cannot reject the null, which means that there is no existence of heteroskedasticity. The test results are shown in Table 7. Based on Table 7 , we can conclude that the model doees not suffers from heteroskedastisitas problem.

Table 5: Estimation Result of Economic Growth

\begin{tabular}{lrrl}
\hline \multicolumn{1}{c}{ Variable } & Coefficient & \multicolumn{1}{c}{ t-Statistic } & \multicolumn{1}{c}{ Prob. } \\
\hline C & 28.00460 & 2.887966 & $0.0098^{* *}$ \\
Investments & 0.000638 & 0.526195 & 0.6052 \\
Labor force & $-1.46 \mathrm{E}-05$ & -2.351590 & $0.0303^{* *}$ \\
Government spending & $7.67 \mathrm{E}-10$ & 1.954987 & $0.0663^{*}$ \\
Crisis & -16.55878 & -10.22117 & $0.0000^{* *}$ \\
OTDA & 0.981105 & 0.734605 & 0.4720 \\
R-squared & 0.867231 & & \\
Adjusted R-squared & 0.830351 & & \\
F-statistic & 23.51477 & & \\
Prob (F-statistic) & 0.000000 & & \\
\hline Note: Enties in & & &
\end{tabular}

Note: Entries in **, $*$ show significantt at $5 \%$ and $10 \%$, respectively

Table 6: Correlations across Independent Variables

\begin{tabular}{lccc}
\hline \multicolumn{1}{c}{ Variable } & Investments & Labor force & Government Spending \\
\hline Investments & 1 & 0,201298 & 0.259470 \\
Labor force & 0.201298 & 1 & 0.926407 \\
Government Spending & 0.259470 & 0.926407 & 1 \\
\hline
\end{tabular}

Table 7: Heteroskedasticity Test using White Test

\begin{tabular}{|c|c|c|c|}
\hline \multicolumn{4}{|c|}{ Heteroskedasticity Test: White } \\
\hline F-statistic & 4.434098 & Prob. F(14,9) & 0.0151 \\
\hline Obs*R-squared & 20.96106 & Prob. Chi-Square(14) & 0.1026 \\
\hline Scaled explained SS & 16.80797 & Prob. Chi-Square(14) & 0.2666 \\
\hline
\end{tabular}




\section{Autocorrelation test}

This study uses Breusch-Godfrey serial correlation LM test to detect the presence of autocorrelation (AC). To determine the lag length, this study uses the method of trial and error with the absolute Akaike criteria as benchmark by finding the smallest value. $\mathrm{H} 0$ is the condition of the absence of AC. From Table 8, the probability of chisquare is 0,1580 . This means that we cannot reject the null, which means that there is no $\mathrm{AC}$ problem.

\section{Normality test}

Normality test is done to detect whether the residuals are normally distributed. The method used to detect the presence of normality is the Jarque-Bera test. The null is that the residuals are normally distributed. Figure 2 shows that the probability value is 0.224508 so that we cannot reject the null. Thus, we can conclude that the residuals are normally distributed.
This paper uses $\mathrm{F}$ test to indicate whether independent variables altogether influence the dependent variable. The null is that, overall, the independent variables do not significantly influence the dependent variable. The results of the analysis in Table 5 show the calculated $F$ value is 23.51477 with a probability of 0.000000 , so thatwe can reject the null.

Table 5 also shows the coefficient of determination of 0.867231 , which means that $86.72 \%$ of the variation in investments, labor force, government spending, as well as the dummy variable monetary crisis and regional autonomy can explain the variations in economic growth.

\section{Regional autonomy}

Table 5 shows that the value of t-test and the probability of regional autonomy is 0,734605 and 0,4720 , respectively. With a significance level of $5 \%$, we cannot reject the null, so that it can be concluded that regional autonomy does not affect economic growth.

Table 8: LM Test for Autocorrelation

\begin{tabular}{lcll}
\hline Breusch-Godfrey Serial Correlation LM Test: & \\
\hline F-statistic & 1.453567 & Prob. F(2,16) & 0.2630 \\
Obs*R-squared & 3.690205 & Prob. Chi-Square(2) & 0.1580 \\
\hline
\end{tabular}

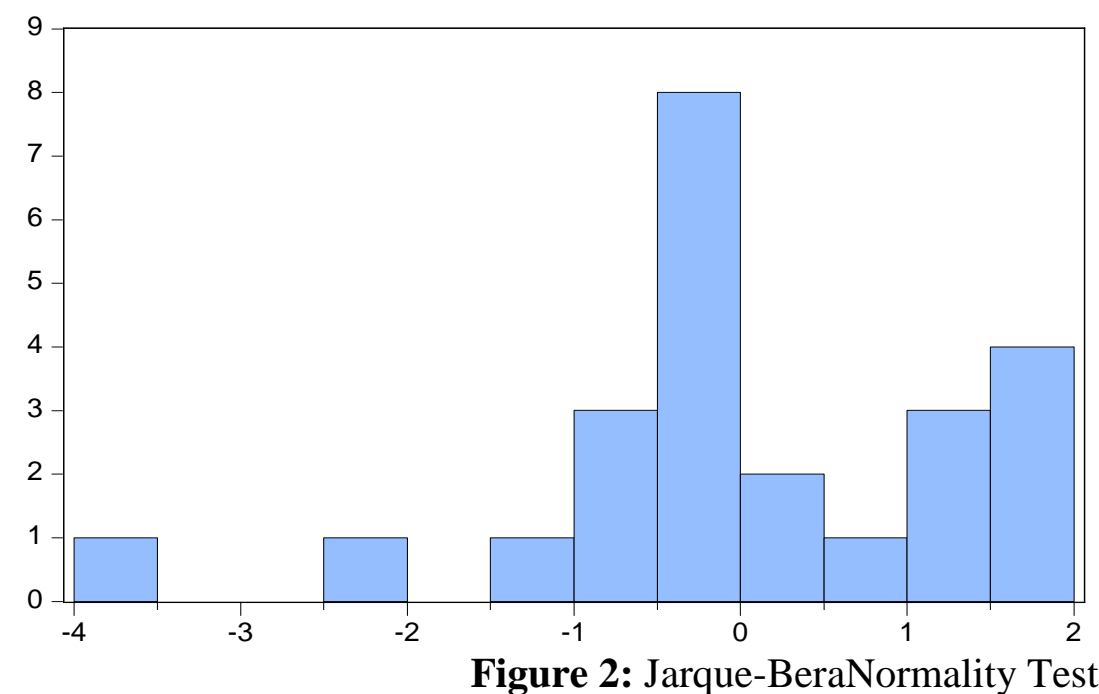

$\begin{array}{lr}\text { Series: Residuals } \\ \text { Sample 1990 } 2013 \\ \text { Observations } 24 \\ \text { Mean } & -1.02 \mathrm{e}-14 \\ \text { Median } & -0.216616 \\ \text { Maximum } & 1.823710 \\ \text { Minimum } & -3.783166 \\ \text { Std. Dev. } & 1.344910 \\ \text { Skewness } & -0.752221 \\ \text { Kurtosis } & 3.851081 \\ & \\ \text { Jarque-Bera } & 2.987686 \\ \text { Probability } & 0.224508\end{array}$

Figure 2: Jarque-BeraNormality Test 
Regional autonomy is the rights, power and obligations of the regions to organize and manage the development of its own state in order to boost economic growth and the achievement of social welfare. The implementation of regional autonomy in YST is expected to optimize the potential and existing resources to conduct its own regional economic development. Thus, the implementation of regional autonomy is expected to increase economic growth in the region. However, this study reject the hypothesis.

This study suspects that it is because the government of YST has not been independent yet. It can be seen from YST dependence on transfers from the central government in the form of general allocation funds (GAF). Some studies have also shown the same phenomenon in other areas in Indonesia, where the ratio of GAF to total regional revenue exceeds $50 \%$. The dependence of YST government on central government funding was caused by its inability to develop the potential and the resources that exist in the region. The results of this study do not support the results of Badruddin (2011) who found that the regional autonomy policy affect the economic growth in Indonesia.

\section{Monetary crisis influence on economic growth}

Table 5 shows that the value of t-test and the probability of monetary crisis is 10.22117 and 0,0000 , respectively. With a significance level of $5 \%$, we can reject the null, so that it can be concluded that monetary crisis affect economic growth. These results are inconsistent with the hypothesis thatthe monetary cris is decreases economic growth. The monetary crisis that occurred in Indonesia since its inception in July 1997, has turned into an economic crisis at the end of the year. The weakening of the rupiah against the US dollar has caused prices to rise dramatically. Many of these companies fired their labors in a massive scale that triggered unemployment. This in turn has reduced the economic growth. These findings prove the link between globalization and the economy of the states as proposed by Brooks (1998), Chamberlin (2010), and Cheong and Wu (2013).

\section{Investment influence on economic growth}

Table 5 shows that the value of t-test and the probability of investment is 0.526195 and 0,6052 , respectively. With a significance level of $10 \%$, we cannot reject the null, so that it can be concluded that investment does not affect economic growth. These results are inconsistent with the hypothesis that the number of investment increases economic growth. We hypothesized that the negative effect is caused by the inability of YST in creating jobs for the labor force. In these conditions, the labor force would trigger unemployment, which in turn lowers economic growth. However, these results are consistent with the results of Prasetyo et al. (2013) who found that the investments do not affect the economic growth of DIY. Presumably it is because investment in YST is dominated by small industries. Small industrial allegedly only affects only employment, but are not able to affect the economic growth.

\section{Labor Force Influence on Economic Growth}

Table 5 shows that the value of t-test and the probability of labor force is -2.351590 and 0.0303 , respectively. With a significance level of $5 \%$, we can reject the null, so that it can be concluded that labor force negatively affects economic growth. These results are inconsistent with the hypothesis that the number of labor force increases economic growth. We hypothesized that the negative effect is caused by the inability of YST in creating jobs for the labor force. In these conditions, the labor force would trigger unemployment, which in turn lowers economic growth. 


\section{Government spending influence on eco- nomic growth}

Table 5 shows that the value of $t$-test and the probability of government spending is 1.954987 and 0.0663 , respectively. With a significance level of $10 \%$, we can reject the null, so that it can be concluded that government spending positively affects economic growth. These results are consistent with the hypothesis that decentralization has a positive impact on economic growth (Badruddin, 2011). This is because government spending is used to boost economic growth, such as to improve the infrastructure so that the mobility of people to generate economic growth increases.

\section{Conclusion}

This paper found that the financial crisis significantly and negatively influenced economic growth in the Special Region of Yogyakarta. This means that the monetary crisis in Indonesia has a bad impact on the economy of the area in the province, which is to reduce economic growth. Regional autonomy has no significant effect on economic growth in Yogyakarta. The implementation of regional autonomy is not yet able to improve the economy of the province. This happens because Yogyakarta has not been able to see and process potentials it has.

This paper also found that the investment does not significantly influence economic growth in Yogyakarta. This occurs because the Yogyakarta -dominated investment in small industries. This small scale industry reduces employment, but does not influence economic growth. The labor force had a negative effect on economic growth in Yogyakarta. This happens because the labor force is not accompanied by sufficient job opportunities. Government expenditure had a positive influence on economic growth in Yogyakarta. This is because government spending is used to improve infrastructure, so that the mobility of people to generate economic growth has increased. To boost economic growth, the Government should use the government spending to improve the condition of infrastructure. The government is expected to allocate government spending proportionally between direct expenditure and indirect expenditure that favored the interests of the public, so as to provide a positive effect on increasing economic growth in Yogyakarta.

\section{Acknowledgement}

The authors would like to thank the Center for Economic Studies (Pusat Pengkajian Ekonomi, $P P E$ ), Fa ulty of Economics, Universitas Islam Indonesia, which provided funding for this study.

\section{References}

Badrudin, R. (2011) "The Effect of Fiscal Decentralization on Capital Expenditure, Growth and Welafare," Economic Journal of Emerging Markets, 3(3), 211-223.

Baek, J. and Koo W.W. (2009) "A Dynamic Approach to the EnvironmentFDI Nexus: The Case of China and India," Journal of International Economic Studies, 13(2), 87-108.

Barro, R. J. (2001) "Economic Growth in East Asia Before and After the Financial Crisis," NBER Working Papers, 8330.

Brooks, D.H. (1998), "Challenges for Asian's Trade and Environment," Economic Staff Paper, No. 57, Asian Development Bank, Manila, Philippines.

BPS-Statistics Indonesia (2014), "Statistics of D.I. Yogyakarta," Yogyakarta.

BPS-Statistics Indonesia (2014), "Local Government Budget Report," Yogyakarta.

Chamberlin, G. (2010) "Output and Expenditure in the Last Three UK Re- 
cessions. Economic \& Labour Market Review, 4(8), 51-64.

Cheong, T., and Wu, Y. (2013), "Globalization and Regional Inequality in China," UWA Discussion Paper, 13(10), 1-34.

Cheung, O.L. (2014) "Economic Growth: An Examination of State Per Capita GDP and Personal Income," Journal of Business \& Economics Research, 12(3), 257-271.

Clowes, D. (2010) "GDP Percapita Growth Performance and Its Sources, Polish Regional Macroeconomic Dimasions 2000-2006," Oeconomica, 55(3), 89-101.

Cole, M.A.,. Elliott, R.J and Zhang, J. (2011), "Growth, Foreign Direct Investment, and the Environment: Evidence from Chinese Cities," Journal of Regional Science, 51(1), 121-138.

Fan, S., Kanbur, R., and Xiaobo, Z. (2011), "China's Regional Disparitas: Experience and Policy," Review of Development Finance, 1(1), 47-56.

Ferdinan, H. (2013) "The Impact of Technological Growth on Economic Per- formance in Indonesia," Economic Journal of Emerging Markets, 5(1), $15-24$.

Hakim, D.B. (2011) "Economic Growth, Trade, and Environmental Issues: Testing Environmental Kuznets Curve," Economic Journal of Emerging Markets, 3(3), 299-313.

Prasetyo, B.A., Priyarsono, D.S. and $\mathrm{Mu}-$ latsih, S. (2013) "Infrastructure, Economic Growth, and Inequality in Indonesia Land Borders," Economic Journal of Emerging Markets, 5(2), 99-108.

Radelet, S. and Sachs, J.D. (1998), "The East Asian Financial Crisis: Diagnosis, Remedies, Prospects," Brookings Papers on Economic Activity, 1, 1-90.Razak, A.R. (2011) "Economic Growth and Regional Development Disparity in South Sulawesi," Economic Journal of Emerging Markets, 3(3), 275-287.

Shindo, Y. (2010), "The Effect of Education Subsidies on Regional Economic Growth and Disparities in China," Economic Modelling, 27(5), 1061-1068. 